\title{
Positioning groups across time: a qualitative analysis of the use of temporal account in commemorative political statements
}

\section{Theofilos Gkinopoulos}

To cite this article: Theofilos Gkinopoulos (2017) Positioning groups across time: a qualitative analysis of the use of temporal account in commemorative political statements, Qualitative Research in Psychology, 14:3, 288-314, DOI: 10.1080/14780887.2017.1290176

To link to this article: https://doi.org/10.1080/14780887.2017.1290176

Accepted author version posted online: 02

Feb 2017.

Published online: 03 Mar 2017.

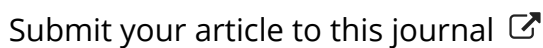

凹 Article views: 111

Q View related articles $\sqsubset$

View Crossmark data \ulcorner 


\title{
Positioning groups across time: a qualitative analysis of the use of temporal account in commemorative political statements
}

\author{
Theofilos Gkinopoulos
}

Loughborough University, Department of Social Sciences, Loughborough, United Kingdom

\begin{abstract}
The present study explores how the leaders of two political parties, the party in power New Democracy (ND) and one of the parties in opposition SYRIZA, depict ingroups and outgroups using a past, present or future account, when representing their group identities. It focuses on commemorative statements made by political leaders on the anniversaries of the restoration of the Greek democracy in 1974. Statements from five different years are analysed: 2004 (the year when Greece hosted the Olympic Games and values of democracy were associated with the Olympic ideals), 2006, 2008, 2012, and 2014 (two of the years of economic crisis). Analysis concerns the rhetorical framing of the restoration of democracy by leaders, focusing on the use of past, present or future account in group representations. Findings identified three key issues around which political leaders shape their temporal account: temporal slippage from past categories to the current political parties versus horizontal comradeship between them, reflections on ingroup history versus expected future outcomes, denial of spatiotemporal co-existence of competing groups versus ongoing co-existence between ingroups and outgroups across time in the political landscape. Findings are discussed under the light of social identity theory and the consideration of different temporal accounts as identity maintenance strategies.
\end{abstract}

\section{KEYWORDS}

Identity; ingroup; outgroup; time

\section{Introduction}

Significant political events, milestones for a state's establishment, are usually described or commemorated in historical terms. However, social psychology, in particular the social identity approach, has been criticized for its failure to systematically bring the historical contexts into its theories and practice (Tajfel 1972; Condor 1996). Consequently, it overlooks the complete variability of social groups in identity formation across time (Tajfel 1969) and the need to remove from group processes in a specific period of time to their positioning in a temporal context (Condor 1996).

CONTACT Theofilos Gkinopoulos T.Gkinopoulos@lboro.ac.uk E Loughborough University, Brockington Building, Margaret Keay Road, Loughborough LE11 3TU, United Kingdom. 
Several academic approaches have developed in terms of the inclusion of time in identity construction. For example, psychological theories of autobiographical memory consider their functions for individuals in many aspects (Conway \& Pleydell-Pearce 2000; Pillemer 2003; Bluck et al. 2005; Williams, Conway \& Cohen 2008). They stress the role of past experiences and personal memories in creating a coherent personal identity over time, which helps people reconstruct the past, cope with negative situations, maintain a desirable mood and a positive self-image, or direct their future decisions and actions. As Brockmeier (2002, p. 21) states, through memory "we give shape to our experience, thought and imagination in terms of past, present and future." Narrative approach in psychology as it is introduced by Sarbin (1986) also considers the development and maintenance of a sense of self in a storied form. Even more recent approaches of narrative psychology (Bamberg \& Andrews 2004; Laszlo 2008, 2011) have taken seriously the issues of identity construction, functioning, and meaning across time.

Beyond the psychological literature, cultural, anthropological, and memory studies have also considered various ways in which historical, temporal accounting provides the means of constructing collective identities (Wertsch 2012; Cubitt 2007). It situates individuals as members of social groups in a social context sharing currently available cultural tools to represent their past. Misztal (2003, p. 7), in emphasizing more on memory studies, clearly states that "collective memory is defined as the representation of the past, both that shared by a group and that which is collectively commemorated, that enacts and gives substance to the group's identity, its present conditions and its vision of the future." Finally, studies in political rhetoric (Hill 2008) have also drawn attention to the ways that historical accounting is used by political speakers in representations of national history to construct national identities. Representations of the past emerge in response to ongoing changes in current socio-political contexts taking the form of commonly shared narratives.

At this point it is worth mentioning that studies closer to social identity processes have attempted to incorporate time dimensions. It has already been known since Goffman's (1959b) study on presentation of self in everyday life that individuals and social groups tend to present a positive self or group image highlighting a desired version of themselves in the future or their positively evaluated history in the past. Similarly, Cinnirella (1998) argues for "possible social identities" as an alternative strategy to cope with negative social identity, which describes "individual and shared cognitions about possible past group memberships, possible future group memberships and perceptions of the past and possible future for current group memberships" (p. 227). Accordingly, he defines possible selves as "individuals' beliefs about what the self was in the past and might become in the future" (p. 229). A "possible social identity" approach offers a wider consideration of groups' 
histories, groups' current status, and their future and gives individuals or groups the potential to deal with negative identities by deploying past images, current situations, or visions of the future. Furthermore, Liu and Hilton (2005) point on the role of history as "the means which provides us with narratives that tell us who we are, where we came from and where we should be going" (p. 1) becoming highly important for the construction of group identities, values and norms, as well as the relations with other social groups and the challenges that should be faced in an intergroup context.

Condor (2006) refers to the notion of "temporal comparison," which has been addressed by a body of work in social identity literature. This term was found in Albert's (1977) work referring to the consistent sense of self over time. It describes the judgement of the present status of individuals or groups against their own past. In a national level, nations as groups are compared to their past group image in order to shape positive intra-national judgements in the present. In an empirical level, a variety of methodological approaches has been used to incorporate time dimensions in social identity dimensions.

One relevant work is that of Reicher's (1996) and Drury and Reicher's (2000) on social movements. They suggested a social identity approach of crowd behaviour according to which crowd action is determined by and determines societal factors. Examining the intergroup conflict during the Battle of Westminster (a riot, where police and activists clashed during a march over a decision of replacement of student grants with student loans) they focused on the consequences of event participation on social identity through different phases of this event. During that phases dynamic relationships developed between groups that took part, as a result of an ongoing interaction or conflict. They aimed to uncover the way that crowd events are developed over time as crowd phenomena.

Later, experimental studies focused on intergroup and temporal comparisons, where participants were primed to make positive evaluations of their own nation either through intergroup comparisons with other nations or through temporal comparisons with the past of their own nation (Mummendey, Klink \& Brown 2001; Nigbur \& Cinnirella 2007). On the contrary, Brown and Haeger (1999) used a content analytic approach and asking participants through an open-ended question "what came to mind when thinking of your country" (p. 34), where a temporal comparison was defined as any statement in which participants referred to some time or event in the past or future when assessing or demarcating characteristics of their own country.

Another body of studies that includes time in social identity construction concerns the concept of perceived collective continuity (Reicher \& Hopkins 2001; Sani et al. 2007) or historical continuity (Jetten \& Hutchison 2011). Both terms refer to people's tendency to perceive their various ingroups (families, nations, etc.) as not only entities that 
exist in the present time but also as entities that move through time displaying a temporal continuity. Sani, Herrera and Bowe (2009) state also that "ingroup constitutes a temporally enduring meaning-system, a persistent and continuous collective entity that, as such, imbues life with meaning, order and permanence..." (p. 3). A distinction was made between cultural and historical perceived collective continuity (Sani, Bowe \& Herrera 2008; Sani, Herrera \& Bowe 2009). The former refers to a perception of a transgenerational transmission of values, beliefs, and traditions. The latter refers to the perceived interconnection between different ages and events throughout the group history that are included in a coherent narrative. In these studies perceived continuity was assessed on the basis of questionnaires, where people should specify their agreement with items addressing the perception of cultural continuity (e.g., "Italian people have passed on their traditions across different generations") and of historical continuity (e.g., "Major phases in Italian history are linked to one another").

Despite the research interest in incorporating time in studies on social identity construction, Condor (1996) points out that these approaches still remain limited. As she argues, an emphasis has been given on experimentally created groups, where participants' or groups' temporal positioning is manipulated, or on intergroup relations as evolved in a single event within a specific moment in time. This perspective overlooks the real temporal context, where groups can be positioned in. Specifically, it is not given the opportunity to people and groups to develop possible historical narratives relating to who they were in the past, who they are now, or who they can become. Furthermore, Cinnirella (1998) notes the need for methodological flexibility so that past social identities to be theorised in a way that past, present, and future can be reconsidered and integrated in order to form meaningful individual or group narratives. Although later studies tried to incorporate the concept of time in social identity and people's group memberships, they remained focused on using questionnaires and assessing changes mainly in intra-individual dimensions such as identification with the group and levels of psychological adjustment (Amiot et al. 2010), feeling of belongingness and development of individual self-concept through membership in different groups integrating different social identities (Amiot et al. 2015). Even though there are some studies, which adopt a qualitative and discursive approach to the construction of identities (e.g., Giles 2006; Reicher 1996; Reicher \& Hopkins 1996, 2001), existing research still tends to treat temporal dimensions as experimental conditions neglecting other, alternative ways in which identities are formed through historical considerations (Condor 2006). Even more recent studies point out the need for a theoretical and methodological framework that can clearly explain the complexity of group identities formation (Koller 2012) and the inclusion of temporal 
account as a fundamental human activity that highlights interesting aspects of group identities with practical and political effects (Hom \& Solomon 2016).

This study explores the ways that political leaders of two political partiesND and SYRIZA-represent ingroups and outgroups in commemorative statements of the restoration of the Greek democracy using historical, temporal account. This study goes beyond the existing consideration of time in identity processes allowing us to show how temporal representations are presented in practices such as commemorative statements, which constitute rhetorical performances. It means that the process of construction of group identities is positioned outside the experimental lab and through such practices like commemorations it becomes feasible to see how political leaders using language imagine and position social actors to affirm their own preferred version of the commemorated event. Consequently, this consideration allows us to see how political leaders create group identities with the help of historical narratives and how groups, figures and other historical social actors are temporally positioned and constituted in relation to them, in order to reinforce their group identities (Charland 1987; Sloanne 2001; Thieme 2009). Furthermore, a selection of materials from different years allows us to consider temporal accountings in representation of group identities from a dynamic perspective, as evolved over time and not as limited to and represented in a particular moment in time. It enables us to uncover the ongoing link between past, present and future group-related narratives in group identity maintenance and gives possible insight into theorising different temporal accounts as alternative strategies that political leaders use to manage their group identity.

\section{Historical background}

It was in 1965, when Greece was under crowned republic and then Prime Minister George Papandreou was maintaining conflicting relations with the King Constantine. Papandreou's intended progressive reforms was the main reason of that conflict. It led to his resignation and to a call for elections on May 1967. Then a group of army officers took the power claiming for the need to deal with the rise of left-wing ideologies and movements and the reforms that Papandreou intended to implement (Colovas 2007; Poulantzas 1977). Greece entered a period of seven years of a military dictatorship.

On 24 July 1974, the seven-year dictatorship (1967-1974) fell and Constantine Karamanlis, the founder of ND, with his the National Unity government took over the country. A few months later, as the leader of ND he called for elections, where he was elected as the first prime minister after the fall of dictatorship and started the work for the restoration of democracy. 
Since 1974, every year political leaders of all political parties of the Greek parliament commemorate this anniversary of the restoration of the Greek democracy issuing also their own ceremonial statements.

ND was founded in 1974 by Constantine Karamanlis. It is a liberalconservative political party, which represents and defends civil liberties, capitalism and conservative positions. In the modern Greek political landscape in general, and specifically during the period that the data of this study covers, ND has been one of the largest and most dominant political parties and the political party in power (Urwin 2014). On the other hand, the Coalition of the Radical Left is a Greek political party also known by the abbreviation SYRIZA. It was founded in 2004 first as a coalition among communist, ecological, and other left-wing parties and movements with Nikos Constantopoulos as the then chairman. It comprises an array of social democrats, socialist, environmentalist, and anti-capitalist groups, as well as Marxist-Leninists and Eurosceptics. During the period the data cover, it was a political party in opposition directing a small percentage of the electorate, around $5 \%$, as long as there was a constant preference toward other, large political parties (March 2008). However, in 2014 it started to become more and more popular.

Although the politically smooth period that Greece spent especially between 2004 and 2009 with a relative economic growth and political stability, four decades after its reinstatement the Third Hellenic Democracy is dealing with crucial issues that challenge its institutional and social foundations. After almost 40 years of normal democratic life and events such as the Olympic Games in 2004 that constituted glorious periods for Greek history when democratic ideals were again revived, this period has seen significant changes on an institutional level, especially after the economic crisis of 2010. These changes signal significant transformations in political system and attitudes, while collective political identities undergo a re-consideration (Dalakoglou 2012).

\section{Methods}

\section{Material collection and rationale}

This study used a series of commemorative statements made by political leaders of ND and SYRIZA on the anniversaries of the restoration of the Greek Democracy on 24 July 1974. These statements are issued every year on 24 July on the official web page of the Greek parliament. Ceremonial statements of five different years were selected and analysed: 2004 (the year when Greece hosted the Olympic Games and democratic ideals and values were associated with this occasion), 2006 and 2008 (as two years within a smooth political period and a period of relative stability), and 
2012 and 2014 (as two of the years within a period, when Greece was affected by economic crisis and democracy and the democratic nature of political parties was questioned). The selection of this data was made out of a range of data set to highlight all the themes that it arises in terms of the various temporal accountings of political leaders. Considering the use of various temporal accounts by political leaders as a strategy to represent their group identities, the selection of commemorative statements of these two political parties, instead of one, was made to depict the process of discursive construction of group identities using temporal account as it takes place in groups of different statuses-a political group of higher status, which is ND as the political party in power, and a political group of lower status, which is SYRIZA as the political party in opposition. In a general sense and speaking of group identities, commemorative statements convey values, norms, and beliefs, which are all important elements of group identity (Sauer 1996). Furthermore, they address groups and people who are commemorated and honoured, as well as political opponents as outgroups (Leudar \& Nekvapil 2004), which offers a view of the group processes that take place in a political intergroup framework, where political leaders represent their group identity.

\section{Analytic procedure}

The analysis involved inductive investigation of forms of temporal account. It consisted of several phases which are partly drawn from iterative grounded theory method of constant comparisons across the data set (Glaser \& Strauss 1967). Initially, all parts of statements that refer to identity issues were identified. These identity parts had to do with groups, figures, or movements and related beliefs or practices, which are all used by political leaders as the basis to interpret social reality, communicate their preferred version of the commemorated event, or define their political goals, all being important elements of a group identity definition. In a next stage, the extracts mentioned just before invoking identity issues were classified as to whether they refer to ingroups (political parties themselves or other groups, figures, or practices ideologically consonant with them and in line with their group norms and values) or outgroups (other groups, figures, or practices ideologically dissonant with political parties' group norms and values). Finally, the identified extracts referring to ingroups and outgroups were classified according to their similarities of the temporal account they include addressing past, present, or future group identities, when, for example, making the ingroup history salient and using the historical past as referential point for the current group identities definition, when displaying temporal continuity linking time dimensions as interdependent, or when adopting a future account projecting their group identity into an imagined and desired future 
time. This together with the first step is in line with the research question of representations of group identities by political leaders using temporal account.

\section{Findings}

Political groups and other social categories are temporally positioned in the past, present, or future. These temporal representations were illustrated in three ways, which differ in their emphasis on each of the aforementioned time dimensions (see Table 1). First, there was a difference in temporal account relating to the "fighters of the anti-dictatorship struggle": a temporal slippage from this category that belongs to the past to the current political party, which is presented as the agent of honouring them, was found in ND statements. There, the fighters of the anti-dictatorship struggle were presented as a separate category to ND positioned in the historical past, while ND is positioned in the present time, when honouring and commemorating them. On the contrary, in statements of SYRIZA the fighters of the anti-dictatorship struggle were presented as maintaining a horizontal, ongoing comradeship with the current political party in the present. Specifically, they are presented not as temporally separate and distant category but rather as an ongoing source of inspiration and imitation for SYRIZA in the present time determining in this manner the future outcomes. Second, in representations of political parties as ingroups themselves in ND statements, there was a temporal continuity where the political party and its achievements or figures related to its norms and values were represented through a reference to its historical past and then to the present time and the future as determined by the ingroup history.

Table 1. Findings on representations of group identities by political leaders using temporal account.

\begin{tabular}{|c|c|c|}
\hline Categories & New Democracy & SYRIZA \\
\hline $\begin{array}{l}\text { Fighters of the anti- } \\
\text { dictatorship struggle }\end{array}$ & $\begin{array}{l}\text { Temporally belonging to the past: } \\
\text { New Democracy is presented as } \\
\text { separate group and as the agent of } \\
\text { honouring them in the present } \\
\text { time. }\end{array}$ & $\begin{array}{l}\text { Sense of comradeship: Fighters of } \\
\text { the anti-dictatorship struggle } \\
\text { constitute a source of an ongoing } \\
\text { inspiration for SYRIZA's political } \\
\text { agenda in the present and future. }\end{array}$ \\
\hline $\begin{array}{l}\text { Political parties or figures } \\
\text { related to them as ingroups }\end{array}$ & $\begin{array}{l}\text { Temporal continuity: the past is } \\
\text { used as the referential point, which } \\
\text { has an impact on the present } \\
\text { determining the future. New } \\
\text { Democracy's history becomes } \\
\text { salient. }\end{array}$ & $\begin{array}{l}\text { Prospective account: an imagined } \\
\text { and desired future determines } \\
\text { SYRIZA's political agenda in the } \\
\text { present time. }\end{array}$ \\
\hline $\begin{array}{l}\text { Ideologically opposite to } \\
\text { political parties outgroups } \\
\text { and practices or ideological } \\
\text { positions }\end{array}$ & $\begin{array}{l}\text { Spatiotemporal exclusion: } \\
\text { ideologically opposite to New } \\
\text { Democracy outgroups or ideological } \\
\text { beliefs and practices do not have } \\
\text { history or progress across time. }\end{array}$ & $\begin{array}{l}\text { Temporal co-existence: SYRIZA and } \\
\text { ideologically opposite to this party } \\
\text { outgroups or ideological beliefs } \\
\text { and practices co-exist and evolve at } \\
\text { the same time. }\end{array}$ \\
\hline
\end{tabular}


Conversely, the statements of SYRIZA included a more prospective account mainly addressing expected outcomes of current policies or actions and an imagined or desired future, which determines these present actions and political agenda. Finally, in terms of outgroups, although in ND outgroups were systematically excluded by the spatiotemporal political landscape as they should have not been existed or as belonging to a distant past without having history or progress across time, in SYRIZA statements there was an ongoing temporal co-existence between competing groups across time, with the political party itself and ideologically opposite to it groups or ideological positions co-existing and evolving at the same time.

\section{Fighters of the anti-dictatorship struggle: Temporal separation versus temporal linking}

The fighters of the anti-dictatorship struggle are mentioned in ceremonial statements to describe all those organisations and social movements that developed during the dictatorial regime of 1967-1974, including student movements, communist organisations, and so forth. This category was represented through different temporal accounts in ceremonial statements of ND and SYRIZA, as it will be seen in the following extracts, either as a category that belongs to the past and is not associated with any way with the present political parties, or as a category which, although it belongs to the past, it still inspires current political parties in the present providing a link or a source of analogy.

\section{New Democracy}

\section{Extract 1: 2004}

Thirty years after the restoration of democracy in Greece we honour all the fighters of the anti-dictatorship struggle and particularly the contribution and the offer of the unknown citizen. We pay tribute to the victims of the Cypriot tragedy and struggle for Cyprus to be reunited and for the last wall in Europe to be fallen. Constantine Karamanlis responded to the challenge of times and to the invitation of the Greek people and came to take over the building of democracy, the foundation of institutions and the stopping of dictatorship.

\section{Extract 2: 2008}

The 24 July, as each historical anniversary, is a day of memory and tribute. At the same time, it is a day on which we reflect on our own duty. Today, we honour the many known and the even more inconspicuous fighters of the anti-dictatorship struggle. The people, who stood by Greece in these difficult years. The protagonists of the Political Changeover. We always remember and honour the victims of the Cypriot tragedy. We emphasize that our constant objective is the reunification of Cyprus. 


\section{Extract 3: 2012}

We honour the restoration of Democracy on the Home where it was born. We honour the pioneers of Metapolitefsis (Political Changeover) and the fighters of the seven-year dictatorship. We, in New Democracy, treasure the great democratic achievements of that period, which bear the stamp of the founder of our party, Constantine Karamanlis. At the same time, we leave behind the ailing which developed in the subsequent years.

\section{Extract 4: 2014}

On 24 July there will be completed 40 years from the return of Democracy to the Home it was born. We honour the pioneers of Metapolitefsis (Political Changeover) and the fighters of the anti-junta struggle. On 24 July 1974 Constantine Karamanlis, with the consent of the Greek people, took over the country wounded by the 7-year dictatorship and the Turkish invasion of Cyprus.

What we first note in these extracts, except 2006, is the reference to the fighters of anti-dictatorship struggle as a category that is positioned in a past time and honoured by a separate group, who as the agent of the action of honouring them is positioned in a present time. Starting from 2004, the then leader refers to the "fighters of the anti-dictatorship struggle" and "the offer of the unknown citizen" (1.1-2) as categories to be honoured in the present time as it seems through the first person form verb "we honour" (1.1). A precise sense of time and separation is communicated in the initial phrase "thirty years after the restoration of democracy" (1.1), where the fighters of anti-dictatorship struggle are temporally located. Similarly, in 2008, "the many known and the even more inconspicuous fighters of the anti-dictatorship struggle" are honoured in the present time by another agent, the "wegroup" (1.2). The present tense of the "we honour" comes to position them in the current time in contrast to the past tense of the verb "stood" (1.3), which addresses the fighters of anti-dictatorship struggle and positions them in the historical past.. In a similar vein, in 2012 (1.1-2) and 2014 (1.2-3), the leader of ND refers to "the pioneers of Metapolitefsis and the fighters of the sevenyear dictatorship" and "the pioneers of Metapolitefsis and the fighters of the anti-junta struggle," respectively, as that category that is positioned in the historical past and is honoured on the occasion of these anniversary by the "we-group" as it seems through the verb form in present tense "we honour" (1.1) in 2012 and (1.2) in 2014. It is also worth noting the clear sense of the fighters' positioning in a historical past through the temporally precise phrase of "seven-year dictatorship" (1.2) in 2012 and similarly in 2014 by stating the duration of " 40 years" (line 1) after the restoration of democracy, which is positioned in the past and the honour of the fighters takes place after this event in the present time. What is in common in all instances is the temporal positioning of the category of "the fighters of the anti-dictatorship struggle" 
in the past, while the current "we-group" is presented by the leader as the main agent, who is responsible for honouring them in the present time. With a similar account across all statements, the leaders accomplish this temporal movement from referring to the fighters of the anti-dictatorship struggle that belong to the historical past to the current action of honouring them emphasizing the current "we-group's" role in this action. Adopting such account, they temporally distance these two groups and present them as two separate group entities. The fighters of the anti-dictatorship struggle existed in the past and do not play a role anymore apart from being honoured by the current group. In the following extracts, we will see a different account adopted by the leaders of SYRIZA when referring to the fighters of the anti-dictatorship struggle.

\section{SYRIZA}

\section{Extract 5: 2006}

The tribute we ought to pay to all those who gave their lives and to those who fought for the restoration of Democracy should not be entrapped in stereotypes and meaningless words which dry-out the momentum of a live historical memory. All of us, especially the political forces and the Coalition of the Radical Left party which played a leading role against the seven-year dictatorship are all judged every single day for the consistency of our words...

\section{Extract 6: 2008}

The day of the restoration of Democracy is not just another anniversary we should honour routinely. It is above all a day for paying tribute to the thousands of people who fought, were jailed and sacrificed for dignity, freedom and democracy. Our own debt as the Coalition of the Radical Left is, as it was then, to release those social forces that will fight for a better today and tomorrow.

\section{Extract 7: 2012}

The day of the restoration of Democracy is a day of tribute paid to thousands of people who fought, were imprisoned and sacrificed for dignity, freedom and Democracy. Our own duty as the Coalition of the Radical Left is, as it was then, to fight together with the people for a better present and future, in every place of work and study.

\section{Extract 8: 2014}

Today, on the anniversary of the restoration of Democracy, we honour first and foremost the fighters of the anti-junta movement, of the anti-junta struggle and we, the younger, want to tell them from this Hall that our lives, our course would not have been the same. They are what they are because of their existence, their example, an example of unselfishness, an example of commitment and passion for Democracy. We hail those who at the young age of 20-25 found themselves at 
the forefront of the struggle from the great Alexandre Panagoulis to Nick Kiaos, to Pavlos Klavdianos, to Thanasis Athanasiou-that is, the first anti-junta party of Rigas Ferraios-who were arrested and tortured.

In these statements a temporally different account to ND's is used. Initially, the fighters of anti-dictatorship struggles were described again as a category that should be honoured in the present time in phrases such as "the tribute we ought to pay to all those, who gave their lives..." (1.1) in 2006, "a day for paying tribute to the thousands of people who fought, were jailed and sacrificed..." (1.2) in 2008, "the day of the restoration of Democracy is a day of tribute paid to thousands of people who fought..." (1.1-2) in 2012, and "we honour first and foremost the fighters of the anti-junta movement, of the anti-junta struggle..." (1.1-2) in 2014. However, in most statements this category is directly linked with the current political party of SYRIZA and its political agenda by not simply constituting a category that belongs to the past and is honoured separately by the agents who honour it in the present time, but also by functioning as a source of an ongoing analogy and comparison determining political actions in the present and future and inspiring SYRIZA's political agenda. In 2008 and 2012 the leader described the role of the fighters of the anti-dictatorship struggle as it was seen just before using the phrase "as it was then" (1.3) in 2008, and (1.2-3) in 2012 drew on an analogy between their role in the past and the current role of "the Left" in the present time which is, in accordance to the fighters' activities, "to fight for a better today and tomorrow" (1.4) in 2008 and "to fight together with the Greek people for a better present and future" (1.3) in 2012. Furthermore, a similar account was clearly used in 2014 when the leader linked the current state of affairs and the political group in existence with the role of the fighters of the anti-dictatorship struggle, stating that "our lives, our course would not have been the same. They are what they are because of their existence, their example, an example of unselfishness, an example of commitment and passion for Democracy" (1.3-5). Finally, a less explicit analogy was drawn in 2006, when the then leader simply pointed to the "leading role against the seven-year dictatorship" (1.4) that political forces and the Left party played. In this statement there is a precise temporal positioning through the "seven-year dictatorship" but also a reference to a current group, "the Left party" (1.3), which was identified with the struggle against dictatorship and is now judged on the basis of its actions inspired by that period. It is worth noting that through these accounts the leaders position the group of "the fighters of the anti-dictatorship struggle" together with the current political party of SYRIZA presenting a "deep, horizontal comradeship" (Anderson 1983, p. 16). It implies a sense of 
common identity between these two groups and the purpose, belonging, and nature in general that is maintained across time. Both categories are presented as having a common purpose of fighting against anti-democratic ideologies, belonging to the general Left-wing ideological space. Consequently, the fighters of the anti-dictatorship struggle are presented to fit precisely within the account of the leaders of SYRIZA toward democracy and democratic-related group norms and values that determine the group identity.

\section{"We-groups": Reflections on ingroup historical past versus projecting into future outcomes}

This section refers to the temporal account that is used by political leaders when they represent the ingroup addressing either themselves or the members of their political parties or all the Greek citizens. The difference lies upon the emphasis and reflection on a historical past as a referential point for the present and future for ND and the projection of political actions into an imagined future addressing expected outcomes for SYRIZA. The following extracts constitute examples of the ways that political leaders of these parties position ingroups across time.

\section{New Democracy}

\section{Extract 9: 2004}

Constantine Karamanlis responded to the challenge of the times and to the invitation of the Greek people and came to take over the building of democracy, the foundation of institutions and the stopping of dictatorship. Then, as New Democracy, we established a strong democracy, we definitely solved the State issue and we put the country on the route to Europe.... Today, almost all the Greeks adopt the European prospects of the country, while we are invited in New Democracy to contribute to the creation of a new political culture with a more active participation of citizens in politics.

\section{Extract 10: 2006}

Thirty two years of constant function of Democracy in Greece are completed on Monday, 24 July, which is a result of collective work. We all together succeeded in making the Greek state modern, organised and well-governed. We all together managed to take Greece out of isolation and make it a European country. Today, with a stable and powerful constitution we the Greek people ought to strictly walk the way we paved in July 1974. The way of unity and solidarity....Away from dogmas and obsessions, solely on the basis of collective interest, we are asked to ensure the continuous deepening of Democracy and the further strengthening of its institutions, to lay the foundation for a really powerful and competitive economy. 


\section{Extract 11: 2008}

Together, citizens and political forces, with national responsibility and political maturity, with belief in our potential and confidence between us, with collective effort, we succeeded. We restored democracy. We built solid institutional bases that rendered it steadfast and ensured political normality and stability. Today, with the precious achievement of 34 years of democratic life as our basis and springboard, in an economic situation difficult for the entire world, in a critical turningpoint for the nation and the Greek society, we are invited to confirm in practice our will to move forward united. To override anything impedes our common course.... Today and in the years that come we will continue in the way that we began together and we follow regularly.

\section{Extract 12: 2012}

We, in New Democracy, treasure the great democratic achievements of that period which bear the stamp of the founder of our party, Constantine Karamanlis. At the same time, we leave behind the ailing, which developed in the subsequent years and led the country to the economic and social crisis of the recent years. With consistency and determination we in New Democracy continue the reforms that our country needs.

\section{Extract 13: 2014}

Today 47 years ago, Constantine Karamanlis opened the book of political changeover with the Greek people. An endeavour that appeared difficult but which was achieved with concord and unity and under his strong governing our country acquired firm and resistant Democratic Institutions.... We, in New Democracy, ensure the great democratic achievements of that era and the course of our country in the European Family with the stamp of the founder of our party Constantine Karamanlis. Today we really honour in New Democracy Constantine Karamanlis and the commemoration of the restoration of Democracy because Greece recovers its lost reliability and Greeks their broken dignity. We are working for a new Greece rid of the weaknesses of the past, which provides all Greek people with hope.

The aforementioned extracts refer to the ingroups either in the form of the political party itself or as all the Greek people and their positioning on a temporal continuum from the past to present and future. To begin, in 2004 the leader of ND initiates with an account of the role of Constantine Karamanlis in a past tense "responded" (1.1) and then described the past achievements in relation to what followed Constantine Karamanlis governing such as "... as New Democracy, we established a strong democracy, we definitely solved the State issue and we put the country on the route to Europe" (1.3-4), with all verbs in a past tense showing a retrospective account. Later, he shifts to an account of depicting the present situation by stating, "Today almost all the Greeks adopt the European prospects of the country..." (1.4-5), with the word "today" giving a precise temporal 
sense. He then moves forward to address actions with a future outcome as "we are invited in New Democracy to contribute to the creation of a new political culture..." (1.6), with the verb "we are invited" in a present tense addressing something that currently takes place and leads in something "new" in the future, different from the present. Similarly, in 2006 he starts referring to the past, providing an account of the ingroup achievements and using verbs in past tense such as "we all together succeeded in making the Greek state modern..." and "we all together managed to take Greece out of isolation..." (2-4). Using the "today" (1.4) he precisely links the past to the present time. Addressing the current situation of the State (1.4) he invites the we-group to a series of actions, mentioning "we are asked to ensure the continuous deepening of democracy...to lay the foundation for a really powerful and competitive economy" (1.6-8) and reflecting a future outcome of these actions temporally connecting their present occurrence with their future impact. In 2008 he also initiates with a series of past achievements, which are summarized by the past tense verb "we succeeded" (1.2) and subsequently with the verbs "we restored" (1.2) and "we built" (1.3) in a past tense describing a series of achievements accomplished in the past. In line 4 a passage from past descriptions to the present state of affairs is made through the word "today" (1.4), where the leader describes the current situation on a national and international level and determines the actions that should be taken for securing a better future, mentioning "we are invited to confirm in practice our will to move forward. To override anything impedes our common course" (1.6). With his final statement in lines 7 and 8, "we will continue in the way that we began together and we follow regularly," he present a clear link between the past achievements, the present actions related to the party's political agenda and the future outcomes that are determined by these actions. In 2012 an account based firstly on Constantine Karamanlis's achievements is used (1.1) with the current leader of ND using a present tense "we treasure" to reflect on past achievements that have already been accomplished and then refers to the present time, stating "we leave behind the ailing which developed..." (1.2), which describes current actions and constitutes the basis for creating better future outcomes summarized mainly in his statement, "we in New Democracy continue the reforms that our country needs..." (1.4), with the verbs in the present tense implying a prospective account. The 2014 statement includes a similar account by the leader of ND addressing the past achievements of Constantine Karamanlis "...opened the book of political changeover..." "an endeavour that appeared difficult but which was achieved...," "our country acquired firm and resistant democratic institutions' (1.1-3), and ensuring that the work of his political party in the present time "today" (1.5) will lead to a "new Greece which provides all people with hope" (1.7-8), describing an imagined and desired future and 
something "new" and different to the present. It is interesting to note in all the aforementioned statements that there was a consistent reflection on the group's history through descriptions of achievements accomplished either by a "we-group" or by Constantine Karamanlis, the founder of ND, who constitutes a role model for the current leadership of ND. In any case, the unique heritage of ND becomes salient and, through the consistent use of the past and the ingroup history as a referential point that determines the present and the future, underscores how ND is distinct from other political groups contributing, in that way, to a positive group identity (Jetten \& Hutchison 2011; Tajfel \& Turner 1979). It is through the connectedness with a historical group past and its resuscitation that the leaders of ND come to represent their group identity. The following extracts address the same issue of how the leader through depicting "we-groups" temporally represents this group identity.

\section{SYRIZA}

\section{Extract 14: 2004}

In order for the historical memory of the today anniversary to remain alive, we must work to shape a new dynamics in the new political period that the country has entered, in order for ideals and visions, principles and values such as the solidary and collective defence of democratic freedoms and social rights to be granted.

\section{Extract 15: 2006}

All of us, especially the political forces and the Coalition of the Radical Left party which played a leading role against the seven-year dictatorship are all judged every single day for the consistency of our words, our participation in fights of the people and the youth in order to re-establish Democracy in international relations, to stop the wars, to defeat the imperialistic policy of the USA.

\section{Extract 16: 2008}

Our own debt on the Coalition of the Radical Left is, as it was then, to release those social forces that will fight for a better today and tomorrow. Specifically this period of time, where the politics and democracy are also affected and disdained due to the interweaving and corruptness, constitutes the moment when we as the reformative and radical Left must shape new value principles that will aim to widen democracy.

\section{Extract 17: 2012}

Our duty as the Coalition of the Radical Left is, as it was then, to fight together with the people for a better present and future, in every place of work and study, in every neighbourhood for the protection of our rights in dignity, work and social commodities... Now is the time for us as the Coalition of the Radical Left to 
strengthen our voices, to overthrow the Memorandum policy and the parties that serve this policy, New Democracy and PASOK, to bring Democracy back to the spotlight, to unite our voices with those of the people's all over Europe for an equitable, peaceful, democratic and socialist society.

\section{Extract 18: 2014}

Democracy is shrinking within a context of increasing repression and limitation of social and political rights. At the same time, the increase of the neonazistic extreme right reminds us that the struggles for democracy are more timely than ever before. Today is the time for us on Coalition of the Radical Left to speak up, to overthrow the memorandum policy and the parties that serve it, New Democracy and PASOK, to bring democracy back to the spotlight, to unite our powers with those of the people's all over Europe for a fair, peaceful, democratic and socialist society.

In contrast to what we noted in ND statements, where the ingroup historical past was used as a referential point for determining the present and the future, in SYRIZA there is an emphasis more on determining current actions that result in future outcomes than on reflecting on historical past achievements. To begin, in 2004 the leader with his statement "we must work to shape a new dynamics in the new political period..." (1.1-2) links the present time as the starting point, when the ingroup's "we" work for a future situation, that is, the "new dynamics." The action of work starts in the present addressing a future and imagined outcome. In 2006 a description of the present political situation with the Coalition of the Radical Left as an agent is mentioned as "all of us...are all judged every single day..." (1.1-2), and then a series of actions that should be taken in the present time addressing a purpose and a future outcome are described "to re-establish Democracy, to stop wars, to defeat the imperialistic policy of the USA" (1.3-4). Also, in 2008 the leader initiates his account connecting the present time through the phrase "to release those social forces" (1.1) to an imagined outcome in the future through the phrase "will fight for a better today and tomorrow" (1.1-2), which follows the present action of the "release." $\mathrm{He}$ follows up in line 4 stating, "reformative and radical Left must shape new value principles that will aim to widen democracy," where again he depicts a present action "must shape," which determines a future result "will aim to widen democracy." In 2012 a similar prospective account is used, when the leader clearly addresses the present duty of the Coalition of the Radical Left "to fight together with the people" in order to shape "a better present and future" (1.1), addressing the current action with its desired future outcome and goal. He continues in line 3 with actions that need to be taken in the present time for a future purpose through the phrases "to strengthen our voices" (1.3), "to bring democracy back to 
the spotlight" (1.4-5), "to unite our voices" (1.5) aiming to an imagined future of "an equitable, peaceful, democratic and socialist society" (1.56). Similarly, in 2014 the leader initiates with a description of the current political situation and then a precise sense of time with the word "today" (1.3) positioning "the Coalition of the Radical Left" as the agent in the present time and referring to actions that should be taken in the present, such as "to speak up, to overthrow the memorandum policy...to bring democracy back to the spotlight, to unite our powers..." (1.4-5) and determine an imagined future of "a fair, peaceful, democratic and socialist society" (1.5-6). In contrast to what we saw in ND statements, where an ongoing link between the past, present and future was dominant across statements, here there is a shift to a more present and prospective account. Through such accounts the leader offers a way of constructing group identities based on possible futures, which in turn determine the current political landscape and have implications with respect to the present time and the actions that should be taken now. As a result, in the statements of SYRIZA the future acts as a "determining condition" (Mead 2002) of the present, and the group identity is constructed and represented on the basis of a link between the present situation and actions and the future outcomes. A "political horizon" (Dunmire 2005) seems to determine the group identity of SYRIZA, rather than an identity based on the present time.

So far, we have seen how political leaders temporally represent role models such as "the fighters of the anti-dictatorship struggle" or ingroups either in the form of "we all the Greeks" or, as we saw in SYRIZA, as "the Left." However, in both political parties' statements there are references to outgroups, either in the form of concrete group entities or of ideological practices and positions opposite to ingroups' values and norms. They are also in turn temporally represented in this statements, as we will see in the following section.

\section{Outgroups: Spatiotemporal exclusion versus temporal coexistence between competing groups}

Commemorative statements usually address not only those figures, groups, or events that are commemorated but also political opponents and ideological positions opposite to each ingroup norms and values (Leudar \& Nekvapil 2004). These groups can be either included in or excluded by the political landscape. In the first case, they are presented as having a progress across time with a clear position in the political system. Conversely, in the second case, they are excluded as having no history and existence over time. Consequently, the following extracts will refer to temporal representations 
of such outgroups, when political leaders represent their group identity and situate their parties in an intergroup context.

\section{New Democracy}

Extract 19: 2006

Navigator in our path to the New Era is the large social majority of change and reform. Away from dogmas and obsessions, solely on the basis of collective interest, we are asked to ensure the continuous deepening of Democracy.”

\section{Extract 20: 2008}

Today, with the precious achievement of 34 years of democratic life as our basis and springboard, in an economic situation difficult for the entire world, in a critical turning-point for the Nation and the Greek society, we are invited to confirm in practice our will to move forward united. To override anything impedes our common course. To condemn each attempt of revival of practices of bitterness, polarisation and division.

\section{Extract 21: 2012}

We in New Democracy treasure the great democratic achievements of that period which bear the stamp of the founder of our party, Constantine Karamanlis. At the same time, we leave behind the ailing which developed in the subsequent years and led the country to the economic and social crisis of the recent years.

\section{Extract 22: 2014}

Greece with the help of Greek people and in the European family will make it again. There is no place in democracy for its opponents and those who tarnish parliamentary system. In New Democracy, we are working for a new Greece rid of the weaknesses of the past, which provides all Greek people with hope.

What we can first see in the statements above is that they all include a reference to outgroups usually in the form of ideologically opposite positions, beliefs, or practices to ingroup norms or values. What is common across these statements is an account of a spatial and temporal exclusion of such ideologies from the political landscape. Specifically, in 2006 with the phrase "away from dogmas and obsessions," the leader addresses the practices or beliefs of dogmas and obsessions as opposite to his political party values and using this account through the "away from," temporally excluding them from the current political landscape and the present time, when political decisions should be made for the future. In 2008 although ideologically opposite positions are presented as existing in the present time, the leader invites for their override and condemnation, which aims to their spatiotemporal exclusion from the present and the future political context. In 2012 a spatiotemporal exclusion of the "ailing" encompassing 
all the ideological positions and the possible parties that represent such ideologies is described away from the present time and the future group prospects through the statement "we leave behind the ailing which developed in the subsequent year..." A similar exclusion from the space and time of the current political landscape is also found in 2014, when the leader addresses the "opponents of democracy and those who tarnish parliamentary system" for whom "there is no place in democracy," and then referring to "weaknesses of the past" as groups or ideological positions that should be isolated by the democratic community and be treated as having no progress on time and as remaining in the past without history and continuity. Two things in ND statements appear as common across statements: Firstly, democracy and related values are defined as the standard on which ingroups and outgroups are differentiated. Specifically, from a temporal perspective, outgroup representations convey a source of exclusion with all these ideologically opposite to ingroup norms outgroups and ideologies being positioned in a past time and space, away from the ND and its leaders' one, who are also the producers of commemorative statements and as having no progress, evolvement, and presence across time in the political landscape. Secondly, it communicates an ingroup identity based on an ongoing denial of existence between competing groups-the ingroup and other outgroups. As mentioned again just before, democracy and related values were used as the standard on which groups are defined. These outgroups are compared on a spatiotemporal scale with the work of ingroup based on this standard. By being positioned away from those ingroup achievements and practices, the outgroup seems to be fundamentally other to democracy and outside the parliamentary context.

The next extracts will address the same issue, that is, the outgroup temporal depictions as deployed in statements of SYRIZA.

\section{SYRIZA}

\section{Extract 23: 2004}

It is essential the radical redeployment of political forces with the reinforcement of the Left in the social and political field, the development of mass movements and the essential juxtaposition with the prevalence of media, xenophobia, racism and nationalism, with the neoliberal policies that undermine the social civil rights and our freedoms.

\section{Extract 24: 2006}

All of us especially the political forces and the Coalition of the Radical Left party, which played a leading role against the seven-year dictatorship, are all judged every single day for the consistency of our words, our participation in fights of the people and the youth in order to re-establish Democracy in international relations, 
to stop wars, to defeat the imperialistic policy of the USA, to minimize the regional inequalities and to face the consequences of neoliberal globalization.

\section{Extract 25: 2008}

Our own debt on the Coalition of the Radical Left is, as it was then, to release those social forces that will fight for a better today and tomorrow. Specifically this period of time, where the politics and democracy are also affected and disdained due to the interweaving and corruptness, constitutes the moment when we as the reformative and radical Left must shape new value principles.

\section{Extract 26: 2012}

Democracy is shrinking in a framework of increasing repression and limitation of social and political rights. At the same time, the rise of the neo-nazistic extreme right, Golden Dawn, and the continuing fascist attacks to fellow citizens point out that the fights for Democracy are more timely than ever before. Now is the time for us as the Left to strengthen our voices, to overthrow the Memorandum policy and the parties that serve this policy, New Democracy and PASOK...

\section{Extract 27: 2014}

Democracy is shrinking within a context of increasing repression and limitation of social and political rights. At the same time, the increase of the neo-nazistic extreme right, Golden Dawn, reminds us that the struggles for democracy are more likely than ever before. Today is the time for us as the Left to speak up, to overthrow the memorandum policy and the parties that serve it, New Democracy and PASOK...

In contrast to what we saw in ND statements, where outgroups were temporally excluded and presented as being excluded from the present political space and time, having no progress or change across time or coexisting with ND, in SYRIZA statements competing groups or conflicting ideological positions are temporally co-present with the political party and move also through time. Specifically, in 2004 ideologically opposite positions to ingroup norms and values such as "media, xenophobia, racism, nationalism and neoliberal policies" are presented as sources of juxtaposition and differentiation and, most importantly, as ideologically opposite practices or positions that co-exist in the same temporal and political context with the political party itself, the ingroup. The "prevalence" and the present tense of the verb "undermine" indicate the active presence of outgroups in the current time. Similarly, in 2006, "wars, the imperialistic policy of the USA, regional inequalities and the neoliberal globalization" are presented as competing practices and ideologies with an active temporal co-presence in the social and political context with "the Left" as the ingroup. The present tense in phrases "to stop wars," "to defeat the imperialistic policy of the USA," "to minimize the regional inequalities..." shows that such outgroups in the form 
of ideological beliefs and practices co-exist with SYRIZA, which needs to confront them. "Interweaving and corruptness" (1.3) are also described in 2008 as co-present ideological practices with the political party itself both temporally positioned in the present time. Finally, in 2012 and 2014 the "neo-nazistic extreme right" and the "political parties that serve Memorandum policy" are also mentioned as temporally co-present with the ingroup political opponents, which constitute a threat against democracy and the Left party. The 2012 statement also emphasizes on the progressive character of the neo-nazistic extreme right wing, the Golden Dawn and its movement across time by stating its fascist actions as "continuing," while the use of the phrase "at the same time" in both statements conveys a sense of synchronic evolvement of different groups. The same applies to the temporal co-existence between the Coalition of the Radical Left and its political opponents, New Democracy and PASOK in 2012 and in 2014.

Another point that should be mentioned is the similar initiating point in both statements "Democracy is shrinking in a framework (2012)/within a context (2014) of increasing repression and limitation of social and political rights." With the continuous tense of "shrinking" and the spatial position of the ingroup within a specific state of affairs, ingroups and outgroups are temporally co-present and together evolve across time. Democracy as a standard represents the ingroup and the "increasing repression and limitation of social and political rights" represents the outgroup. It is clear throughout the aforementioned extracts that the leaders of SYRIZA deal with the ingroup identity in terms of representing their political ingroup using its name-and outgroups in the form of ideologically opposite beliefs or practices as co-present at the same time across all the statements, which indicates their direct and immediate differentiation, as well. With this temporal co-existence between competing groups the leaders secure an inclusive ingroup category of the Left tending to directly differentiate it to outgroups. It is a familiar aspect of self-categorization processes and especially of metacontrast-ratio (Turner et al. 1994; Abrams \& Hogg 2010). That means that the leaders of SYRIZA emphasized on presenting stark differences between the political ingroup and other outgroups based on standards of democratic related values such as social, civil, political rights, freedoms, re-establishment of democracy, that consistently define the ingroup identity as homogenous and devoted to such values and related norms.

\section{Discussion}

This analysis captured the temporal account of political leaders in five statements of the anniversaries for the restoration of the Greek democracy. It argues for a positioning of social groups within a temporal lineage that links their past, present and future placement. Different temporal accounts 
were identified when analysing these statements. In terms of the key issues that were identified, first, there was a difference in temporal representations of the fighters of the anti-dictatorship struggle. For the leaders of ND this category belonged to a past time, while they presented the current ingroup as "we," as the main agent in the present time that commemorates a past category and at the same time separated that category from the current ingroup of "we" as "all the Greeks" or the members of ND by presenting two different in time and nature categories. On the other hand, for the leaders of SYRIZA, the fighters of anti-dictatorship struggle and the current ingroup, "the Coalition of the Radical Left" shared a common identity and purpose to fight for democratic values and was linked through a horizontal, analogical relationship-that is, what happened then in the past is happening now in terms of the actions for democracy and related values.

Second, a difference lied upon the temporal account that was used to represent current ingroups, either as "we all the Greeks" or as the members of the political parties and their leaders themselves. The leaders of ND emphasized on a historical past and made their ingroup salient reflecting on its history as determining factor for present and future actions, while the leaders of SYRIZA used a future-based account and the future desired outcomes as determining factors of the present actions based on their group norms.

Finally, in relation to outgroups, for the leaders of ND outgroups, either as specific group entities or as ideologically opposite positions, were temporally excluded from the political landscape being represented as having no history or progress over time, but just as external and threatening for democracy forces that are isolated by the democratic community. In statements of SYRIZA outgroups, in either form again, were represented as temporally co-present. The leaders of SYRIZA were trying to construct their group identity through an ongoing differentiation between competing groupsthe political party itself and ideologically opposite groups or positions as outgroups.

Through this study, political leaders uncovered their group historical narratives in relation to the anniversary of the restoration of the Greek democracy across different years. They represented various social groups as belonging to a historical past, linked to the present time or projected to an imagined future. The question of representations of categories has been of interest for discursive psychology (Potter \& Wetherell 1987; Edwards 1991), which investigates the natural language to understand how representations are achieved in talk or text. However, by pointing to the various temporal accounts in the central topic for social psychology, the representations of group identities, this study opened up the debate on the neglected significance and function of temporality and time-related accounts on social 
psychological processes such as group identities formation. Indeed, Levine (2003) argued for a "time in events" (p. 68) perspective, which suggests that a central issues in social psychology is not just to show that group representations are achieved by or through language but also to show that such representations are positioned across time and become more or less distant from the times of those who represent them. In this respect, it was by looking at the various, inherent temporal accounts that we achieved a clearer understanding of the representations of group identities by political leaders and the ways they move through time.

We should also bear in mind that narratives can be either progressive or regressive (Condor 1997) and respectively that group identities are constructed both on the basis of who the group was in the past and who is now or who can become in the future (Uprichard 2011). A last theoretical point that should be made, is that of connotations and group comparisons. So far, the theoretical interest has focused on comparisons between a present and an ideal historical past, so that positive intragroup judgements to be achieved (Condor 1997). This analysis uncovered not only positive present images as the outcome of a comparison with a glorious historical past in favour of a group continuity and of praising a past that seems more conducive than the present or future, but also negative present images and an imagined future that determines actions in a present time to achieve futurerelated goals.

At a more methodological level, linking the consideration of historical past to projections onto an imagined future in natural contexts such as political texts offers a view of social identity and categorisation processes, which has not been well articulated reflecting an omission in the existed literature and methods (Condor 1996; Cinnirella 1998; Hom \& Solomon 2016). Taking into account the groups' past and the manner that past, present, and future accounts are discursively unfolded and constituted across time provide us with different meaningful historical narratives at a group level, on which political leaders draw to represent and position their group identities and maintain a positive group image. This would not be feasible unless forms of group representations were seen beyond the experimental environment and lab-based studies with artificially created groups and also as they developed in different periods of time, rather than in a single case, for instance in ceremonial statements of a specific year. Given the importance of temporality aspects in representations of group identities and taking into account the general objective of this study of bringing the concept of temporality to social identity approach to leadership by looking at how political leaders used temporal account to represent their group identity, we hope it invites a further discussion on the positioning of group identities across time and on considering various temporal representations as identity-maintenance strategies. 


\section{Notes on contributor}

Theofilos Gkinopoulos is a $\mathrm{PhD}$ student at the Department of Social Sciences of Loughborough University. His research interests fall into the area of group identities in political leadership through commemoration emphasizing the representation of ambiguous and concrete group identities and group identities as they evolve over time incorporating a temporal discourse. Recent work also includes remembering in collaborative settings and representations of personal past through nostalgic experiences.

\section{References}

Abrams, D \& Hogg, MA 2010, 'Social identity and self-categorisation', in JF Dovidio, M Hewstone, P Glick \& VM. Esses (eds.), The SAGE handbook of prejudice, stereotyping and discrimination, Sage, London, pp. 179-93.

Albert, S 1977, 'Temporal comparison theory', Psychological Review, vol. 84, pp. 485-503.

Amiot, C, de la Sablonniere, R, Smith, LGE \& Smith, JR 2015, 'Capturing changes in social identities over time and how they become part of the self-concept', Social and Personality Psychology Compass, vol. 9, no. 4, pp. 171-87.

Amiot, C, Terry, DJ, Wirawan, D \& Grice, TA 2010, 'Changes in social identities over time: the role of coping and adaptation processes', British Journal of Social Psychology, vol. 49, pp. 803-26.

Anderson, B 1983/1991, Imagined communities, Verso, London.

Bamberg, M \& Andrews, M 2004, Considering counter-narratives: narrating, resisting, making sense, Amsterdam, John Benjamins.

Bluck, S, Alea, N, Haberman, T \& Rubin, DR 2005, 'A tale of three functions: the selfreported uses of autobiographical memory', Social Cognition, vol. 23, no. 1, pp. 91-117.

Brockmeier, J 2002, 'Remembering and forgetting: narrative as cultural memory', Culture \& Psychology, vol. 8, no. 1, pp. 15-43.

Brown, RJ \& Haegger, G 1999, 'Compared with what? Comparison choice in an international context', European Journal of Social Psychology, vol. 29, pp. 31-42.

Charland, M 1987 'Constitutive rhetoric: the case of the Peuple Quebecois', Quarterly Journal of Speech, vol. 73, no. 2, pp. 133-50.

Cinnirella, M 1998, 'Exploring temporal aspects of social identity: the concept of possible social identities', European Journal of Social Psychology, vol. 28, pp. 227-48.

Colovas, CA 2007, A quick history of modern Greece, America Star Books, Frederick, MD.

Condor, S 1996, 'Social identity and time', in WP Robinson (ed.), Social groups and identities, Oxford, Butterworth-Heinemann, pp. 285-316.

Condor, S 1997, 'Having history: a social psychological exploration of Anglo-British autostereotypes', in CC Barfoot (ed.), Beyond Pug's tour, Rodopi, Amsterdam, pp. 213-253.

Condor, S 2006, 'Temporality and collectivity: diversity, history and the rhetorical construction of national entitativity', British Journal of Social Psychology, vol. 45, pp. 657-82.

Conway, MA \& Pleydell-Pearce, CW 2000, 'The construction of autobiographical memories in the self-memory system', Psychological Review, vol. 107, pp. 261-88.

Cubitt, G 2007, History and memory, Manchester University Press, Manchester.

Dalakoglou, D 2012, "The crisis before "the crisis": violence and urban neoliberalization in Athens', Social Justice, vol. 39, no. 1, pp. 24-42.

Drury, J \& Reicher, SD 2000, 'Collective action and psychological change: the emergence of new social identities', British Journal of Social Psychology, vol. 39, pp. 579-604. 
Dunmire, P 2005, 'Preempting the future: rhetoric and ideology of the future on political discourse', Discourse \& Society, vol. 16, pp. 481-513.

Edwards, D 1991, 'Categories are for talking: on the cognitive and discursive basis of categorisation', Theory \& Psychology, vol. 1, pp. 515-42.

Giles, D 2006, 'Constructing identities in cyberspace: the case of eating disorders', British Journal of Social Psychology, vol. 45, no. 3, pp. 463-77.

Glaser, B \& Strauss, A 1967, The discovery of grounded theory, Aldine, New York.

Goffman, E 1959b, The presentation of self in everyday life, Doubleday-Anchor, Garden City, NY.

Hill, CL 2008, National history and the world of nations, Duke University Press, Durham, NC.

Hom, A \& Solomon, T 2016, 'Timing, identity, and emotion in international relations', in AR Hom, C McIntosh, A McKay \& L Stockdale (eds.), A space for time: essays on time, temporality and global politics, E-International Relations Publishing, Bristol, pp. 20-38.

Jetten, J \& Hutchison, P 2011, 'When groups have a lot to lose: historical continuity enhances resistance to a merger', European Journal of Social Psychology, vol. 41, pp. 335-43.

Koller, V 2012, 'How to analyse collective identity in discourse-textual and contextual parameters', Critical Approaches to Discourse Analysis across Disciplines, vol. 5, no. 2, pp. $19-38$.

László, J 2008, The science of stories: an introduction to narrative psychology, Routledge, London.

László, J 2011, 'Narrative psychology', in D Christie (ed.), The encyclopedia of peace psychology, Wiley-Blackwell, San Francisco, pp. 687-91.

Leudar, I \& Nekvapil, J 2004, 'Media dialogical networks and political argumentation', Journal of Language and Politics, vol. 3, pp. 247-66.

Levine, M 2003, 'Times, theories and practices in social psychology', Theory \& Psychology, vol. 13 , no. 1 , pp. 53-72.

Liu, JH \& Hilton, DJ 2005, 'How the past weighs on the present: social representations of history and their role in identity politics', British Journal of Social Psychology, vol. 44, pp. 1-21.

March, L 2008, Contemporary far left parties in Europe: from Marxism to the mainstream, Friedrich Ebert Stiftung, Bonn/Berlin.

Mead, GH 2002, The philosophy of the present, Prometheus Books, New York.

Misztal, B 2003, Theories of social remembering, Open University Press, Maidenhead.

Mummendey, A, Klink, A \& Brown, R 2001, 'Nationalism and patriotism: national identification and out-group rejection', British Journal of Social Psychology, vol. 40, pp. 159-72.

Nigbur, D \& Cinnirella, M 2007, 'National identification, type and specificity of comparison and their effects on descriptions of national character', European Journal of Social Psychology, vol. 37, pp. 672-91.

Pillemer, DB 2003, 'Directive functions of autobiographical memory: the guiding power of the specific episode', Memory, vol. 11, pp. 193-202.

Potter, J \& Wetherell, M 1987, Discourse and social psychology: beyond attitudes and behaviour, Sage, London.

Poulantzas, N 1977, The crisis of the dictatorships: Portugal, Greece, Spain, Papazisis, Athens.

Reicher, SD 1996, 'The battle of Westminster: developing the social identity model of crowd behaviour and development of collective conflict', European Journal of Social Psychology, vol. 26, pp. 115-34.

Reicher, SD \& Hopkins, N 1996, 'Self-category constructions in political rhetoric: an analysis of Thatcher's and Kinnock's speeches concerning the British miners' strike (1984-5)', European Journal of Social Psychology, vol. 26, no. 3, pp. 353-71.

Reicher, SD \& Hopkins, N 2001, Self and nation, Sage, London.

Sani, F, Bowe, M \& Herrera, M 2008, 'Perceived collective continuity and social well-being', European Journal of Social Psychology, vol. 38, no. 2, pp. 365-74. 
Sani, F, Bowe, M, Herrera, M, Manna, C, Cossa, T, Miao, X \& Zhou, Y 2007, 'Perceived collective continuity: seeing groups as entities that move through time', European Journal of Social Psychology, vol. 37, no. 6, pp. 1118-34.

Sani, F, Herrera, M \& Bowe, M 2009, 'Perceived collective continuity and ingroup identification as defence against death awareness', Journal of Experimental Social Psychology, vol. 45, pp. 242-5.

Sarbin, TR 1986, Narrative psychology: the storied nature of human conduct, Praeger, Westport, CT.

Sauer, C 1996, 'Echoes from abroad - speeches for the domestic audience: Queen Beatrix' address to the Israeli parliament', Current Issues in Language and Society, vol. 3, pp. 233-67.

Sloane, T (ed.) 2001, Encyclopedia of rhetoric, Oxford University Press, New York.

Tajfel, H \& Turner, JC 1979, 'An integrative theory of intergroup conflict', in WG Austin \& S Worchel (eds.), The social psychology of intergroup relations, Brooks-Cole Publishing, Monterey, CA, pp. 33-47.

Tajfel, H 1969, 'Social and cultural factors in perception', in G Lindzey \& E Aronson (eds.), Handbook of social psychology, vol. 3, Addison-Wesley, Reading, MA.

Tajfel, H 1972, 'Experiments in a vacuum', in J Israel \& H Tajfel (eds.), The context of social psychology: a critical assessment, Academic Press, London, pp. 69-119.

Thieme, K 2009, 'Constitutive rhetoric as an aspect of audience design: the public texts of Canadian suffragists', Written Communication, vol. 27, no. 1, pp. 36-56.

Turner, JC, Oakes, PJ, Haslam, AS \& McGarty, C 1994, 'Self and collective: cognition and social context', Personality and Social Psychology Bulletin, vol. 20, pp. 454-63.

Uprichard, E 2011 'Narratives of the future: complexity, time and temporality', in P Vogt \& M Williams (eds.), Sage handbook of innovation in social research methods, Sage, London, pp. 103-19.

Urwin, DW 2014, The community of Europe: a history of European integration since 1945, Routledge, London.

Wertsch, JV 2012, 'Narrative tools and the construction of identity', in M Schultz, S Maquire, A Langley \& H. Tsoukas (eds.), Constructing identity in and around organisations, Oxford University Press, New York, pp. 128-46.

Williams, HL, Conway, MA \& Cohen, G 2008, 'Autobiographical memory', in G Cohen \& MA Conway (eds.), Memory in the real world, 3rd edn, Psychology Press, London, pp. 21-90. 